\title{
Anti-convulsivant and sedative like-effect of Abyssinone V-4' methyl ether Isolated from Erythrina droogmansiana (Leguminosae)
}

\author{
TALLA Emmanuel $^{1 *}$, NGATCHA Sidoine ${ }^{2}$, NJAPDOUNKE Jacqueline ${ }^{2}$, NKANTCHOUA Gisèle ${ }^{2}$, YAYA Gbaweng \\ Abel Joël ${ }^{3}$, NGO BUM Elisabeth ${ }^{2}$, MBAFOR TANYI Joseph ${ }^{4}$, NJINTANG YANOU Nicolas ${ }^{2}$ \\ ${ }^{1}$ Department of chemistry, Faculty of Sciences, University of Ngaoundere, POBOX 454, Ngaoundere, Cameroon. ${ }^{2}$ Département of biological Sciences, \\ Faculty of Sciences, University of Ngaoundere, POBOX 454, Ngaoundere, Cameroon. ${ }^{3}$ Institute of Medical Research and Medicinal plants Studies \\ (IMPM), POBOX 6163, Yaounde, Cameroon. ${ }^{4}$ Department of Organic Chemistry, University of Yaounde 1, POBOX 812, Yaounde, Cameroon.
}

\begin{tabular}{l}
\hline ARTICLE INFO \\
\hline Article history: \\
Received on: $16 / 06 / 2015$ \\
Revised on: 03/07/2015 \\
Accepted on: 02/08/2015 \\
Available online: 28/10/2015 \\
\hline Key words: \\
Epilepsy, Insomnia, \\
Traditional medicine, \\
pilocarpine, abyssinone V-4, \\
methyl ether.
\end{tabular}

\begin{abstract}
Erythrina droogmansiana is used in traditional medicine in Cameroon to treat epilepsy, insomnia and headaches. From this plant, many secondary metabolites are extracted including alcaloids, tannins, flavonoids, etc. Amongst the flavonoid, abyssinone V-4' methyl ether is used in this manipulation. Animal models of epilepsy: pentylenetetrazol (PTZ), picrotoxine (PIC) and pilocarpine (PILO)-induced convulsions or turning behavior were used to evaluate anticonvulsant activity while diazepam-induced sleep test was used to evaluate sedative activity of the extract. Four doses of extracts were used for each group test $(12.5,25,50$ and $100 \mathrm{mg} / \mathrm{kg})$. Abyssinone V4' methyl ether protected $100 \%$ of mice against the convulsions induced by the pentylenetetrazole at the dose of $100 \mathrm{mg} / \mathrm{kg}$. Abyssinone V-4' methyl ether protected $100 \%$ of mice at the doses of 25 and $100 \mathrm{mg} / \mathrm{kg}$ and $80 \%$ at the doses of 12.5 and $50 \mathrm{mg} / \mathrm{kg}$ against generalized convulsions induced by picrotoxine. This flavonoid protected $100 \%$ of mice at the doses 25 and $50 \mathrm{mg} / \mathrm{kg}$ and $80 \%$ at the doses of $12.5 \mathrm{mg} / \mathrm{kg}$ against generalized convulsions induced by pilocarpine. Moreover, for the test of induction of convulsions by pilocarpine, Abyssinone V-4' methyl ether protected $100 \%$ of mice at doses of 25 and $50 \mathrm{mg} / \mathrm{kg}$ and $71.43 \%$ at the doses of 12.5 and 100 $\mathrm{mg} / \mathrm{kg}$ against death after $1 \mathrm{~h}$ and $24 \mathrm{~h}$ respectively. Abyssinone V-4' methyl ether has anticonvulsivant properties and not sedative properties. These results explain the use of Erythrina droogmansiana to treat epilepsy.
\end{abstract}

Abbreviations: PTZ: Pentylenetetrazol, PIC: Picrotoxin, PILO: Pilocarpine, ED: Distilled water, Ip: Intraperitoneal.

\section{INTRODUCTION}

Epilepsy is a disease that affects about 40 millions people worldwide (Njamshi et al., 2010). In 1968, the prevalence of epilepsy in Africa was about 4.8 to $40 \%$. In 1996, Diop and collaborators reported in Senegal a prevalence of epilepsy of 21 \%o (Diop et al., 1996). In 2006, Ngounou and collaborators estimated the prevalence in sub-Saharian Africa to be two or three times higher than the rate in developed world (Ngounou et al., 2007). In Cameroon, some epidemiological studies on epilepsy have shown that the prevalence of epilepsy is estimated to vary from 5-136/1000. Thus, epilepsy is one of the major public health problems in Cameroon. In Africa and in Cameroon particularly, phytotherapy in traditional medicine still plays an important role in the management of diseases, mostly amongst

* Corresponding Author

E-mail: tallae2000@yahoo.fr populations with very low income (Geoffrey and Kirby, 1996). Phytotherapy relies on the use of a wide variety of plant species including Erythrina droogmansiana. Abyssinone V-4' methyl ether is a prenylated flavonoid isolated from plant Erythrina droogmansiana. 50 flavonoids have been obtained during the last three decades from about 15 species of Erythrina genus (Kamat et al., 1981; Njamen et al., 2003; Kebenei et al., 2011; Mvondo et al., 2012), with prenylated flavonone, isoflavones and pterocarpans being the major non alkaloid secondary metabolites isolates so far (Mvondo et al., 2012; Wandji et al., 1994). Among these metabolites, there are abyssinones which are prenylated flavonoids isolated from Erythrina abyssinica (Kebenei et al., 2011).

These molecules have gained attention since abyssinone II was reported to show aromatase inhibitory activity (Maiti et al., 2007). The antioxidant and cytotoxic activities of abyssinone I, abyssinone II and related compounds have been reported (Rao GV et al., 2009). 
The anti-inflammatory and antioxidant activities of prenylflavanones isolated from Erythrina sigmoidea have been reported (Njamen et al., 2004). Some abyssionones especially abyssinone $\mathrm{V}$ have recently been reported to inhibit the activity of the protein tyrosine phosphatase-1B (PTP 1B), which is directly linked to type-2 diabetes and obesity therapy (Na MK et al., 2006; Kone et al., 2011) and to exhibit estrogenic properties (Mvondo et al., 2012). The anticonvulsivant and sedative property of abyssinone V-4- methyl ether has not yet been evaluated. Therefore, the present study was undertaken to investigate the anticonvulsivant and sedative effect of abyssinone V-4- methyl ether, a prenylated flavonoid isolated from Erythrina droogmansiana.

\section{MATERIALS AND METHODS}

\section{Plant material}

The root bark of E. droogmansiana T. Durand was collected from Nkomekoui, Yaounde-Cameroon in August 2010. Identification and authentication of the plant material was done at the National Herbarium Yaoundé, Cameroon, where a voucher specimen $\mathrm{N}^{\circ} 4261 / \mathrm{SRFK}$ has been deposited.

\section{Extraction and isolation of the compound}

Air-dried and pulverized root bark of E. droogmansiana $(1.2 \mathrm{Kg})$ was extracted successively with ethyl acetate and methanol. The extract was filtered and the solvent evaporated under reduced pressure, $150 \mathrm{~g}$ of residue was obtained. This extract was subjected to chromatography over silica gel packed in n-hexane. Gradient elution was done using n-hexane, ethyl acetate and methanol in increasing polarity to give 7 series of fractions mixed on the basis of TLC. Repeated column chromatography with hexane-EtAOc (90:10) yielded YG4 and other compounds. The structures have been elucidated using spectral methods (MS, NMR, and element analysis).

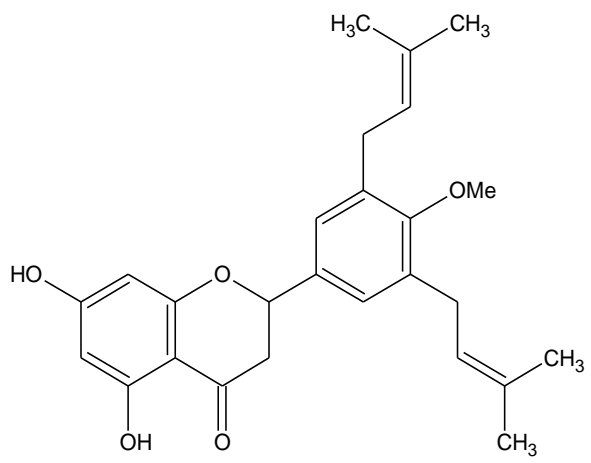

Fig. 1: Abyssinone V-4'-methyl ether.

The compound YD4 was obtained as a white powder (500 mg) and showed a $[\mathrm{M}]+$ at $\mathrm{m} / \mathrm{z} 422.2094$ corresponding to molecular formula $\left(\mathrm{C}_{26} \mathrm{H}_{30} \mathrm{O}_{5}\right)$. This compound was identified as abyssinone $\mathrm{V}-4$ '-methyl ether (Figure 1). The presence of a flavonone skeleton was evident from the ${ }^{1} \mathrm{HNMR}$ spectra at 5.33 $(1 \mathrm{H}, \mathrm{dd})$ and $2.76(1 \mathrm{H}, 2 \mathrm{q})$ corresponding to the $\mathrm{H}-2$ and to the $\mathrm{H}-3$ proton of the $\mathrm{C}$-ring of flavonones respectively. From the ${ }^{13} \mathrm{CNMR}$ spectra, the presence of signal at 79.3 and 42.5 respectively indicated the $\mathrm{C}-2$ and $\mathrm{C}-3$ of the $\mathrm{C}$-ring of flavonone. The ${ }^{1} \mathrm{H}$ and ${ }^{13} \mathrm{CNMR}$ spectra data of this compound were compared to those previously published (Yenesew et al., 1998). Other compounds obtained were droogmascarpine, phaseollidin, stigmasterol and $\beta$-sitosterol.cc All extract were prepared according to traditional healers and chemists, and were administered 1 hour before the tests at the following doses 12.5, 25,50 and $100 \mathrm{mg} / \mathrm{kg}$.

\section{Animals and drug administration}

Adult male mice: Musmusculus Swiss $22 \pm 3 \mathrm{~g}, 2$ months old and obtained from the animal laboratory of our University were used for this study. Abyssinone V-4'-methyl ether and distilled water were given orally to experimental animals after suspending in a mixture of distilled water and $0.5 \%$ dimethylsulfoxide (DMSO). The positive control groups received the same experimental handling as those of the test groups.

\section{Pharmacological tests \\ Diazepam-induced sleep test}

Mice were divided into five groups of 5 mice and received different treatments. Group I (negative control) was treated with distilled water. Groups II to V (test groups) were treated with 4 doses of Abyssinone. The sleep potentiating effects of the plant extracts were studied in mice that had received diazepam (ip) at a dose of $50 \mathrm{mg} / \mathrm{kg} 1$ hour after treatment. The time taken from the loss of the straightening reflex to its regain gave the sleeping time (Ngo Bum et al., 2009a,b; Rakotonirina et al., 2001).

\section{Pentylenetetrazol (PTZ) test}

Mice were divided into six groups of 5 mice each and received different treatments. Group I (negative control) was treated with distilled water. Groups II to V (test groups) were treated with 4 doses of the abyssinone. Group VI clonazepam, 0.1 $\mathrm{mg} / \mathrm{kg}$ ip, was used as positive control. Clonic seizures were induced in mice by the ip injection of $70 \mathrm{mg} / \mathrm{kg}$ PTZ. The protective effect of the different treatments given $1 \mathrm{~h}$ before PTZ injection was recorded. Animals that did not convulse within the $10 \mathrm{~min}$ of observation were qualified protected (Ngo Bum et al., 2010; Ngo Bum et al., 2001; Wamil et al., 1994.).

\section{Picrotoxine (PIC) test}

Six groups of 5 mice each were treated as above. However the positive control group received $0.4 \mathrm{mg} / \mathrm{kg}$ clonazepam ip. Clonic seizures were induced in mice by the ip injection of $7.5 \mathrm{mg} / \mathrm{kg}$ PIC. Mice were observed for $15 \mathrm{~min}$. A protective effect of the different treatments given $1 \mathrm{~h}$ before PICinduced clonic seizures was recorded. Animals that did not convulse within $15 \mathrm{~min}$ of observation were qualified protected (Ngo Bum et al., 2005; Ngo Bum et al., 2001; Bernasconi et al., 1988; Lehmann et al., 1988). 


\section{Pilocarpine (PILO) test}

Mice were divided into six groups of 7 mice each and received different treatments. Group I (negative control) was treated with distilled water. Groups II to V (test groups) were treated with 4 doses of the abyssinone. Group VI Diazepam, 0.3 $\mathrm{mg} / \mathrm{kg}$ ip, was used as positive control. Generalized convulsions were induced in mice by the ip injection of $375 \mathrm{mg} / \mathrm{kg}$ PILO. The scopolamine administered ip (1 $\mathrm{mg} / \mathrm{kg}) 15 \mathrm{~min}$ after different treatments and $45 \mathrm{~min}$ before PILO injection was recorded. Animals that did not convulse and did not die within the following one to 24hours of observation were qualified protected (Ethel et al 2010; Henrik et al., 2003).

\section{Chemicals}

Clonazepam (Rivotril ${ }^{\circledR}$, was from Roche Pharma, ReinachSchweiz); Diazépam: (Valium ${ }^{\circledR}$, was from Roche, Neuilly, France); scopolamine: (hyosinebutylbromude); pentylenetetrazol, picrotoxine: (Sigma Aldrich Inc., St Louis, MO, USA) and pilocarpine (isotopilocarpine).

\section{Statistical analysis}

Three parameters were measured: the protection against convulsion induced by PTZ, PIC and PILO, the latency and the sleeping time. The percentages of protected animals were analyzed using the Fisher Exact Test (two-tail). The Fischer Exact test was used to compare the percentage of protected mice. Data were $\mathrm{p}<$ 0.05 were qualified significant. The ED50 were determined with Statgraphics Plus (confident limits at 95\%).

\section{RESULTS}

Effect of Abyssinone on diazepam-induced sleep in mice.

Abyssinone V-4' methyl ether protected mice for convulsions induced by chemically substances. In diazepaminduced sleep test, the abyssinone not increased sleeping time of the control group (fig.2).

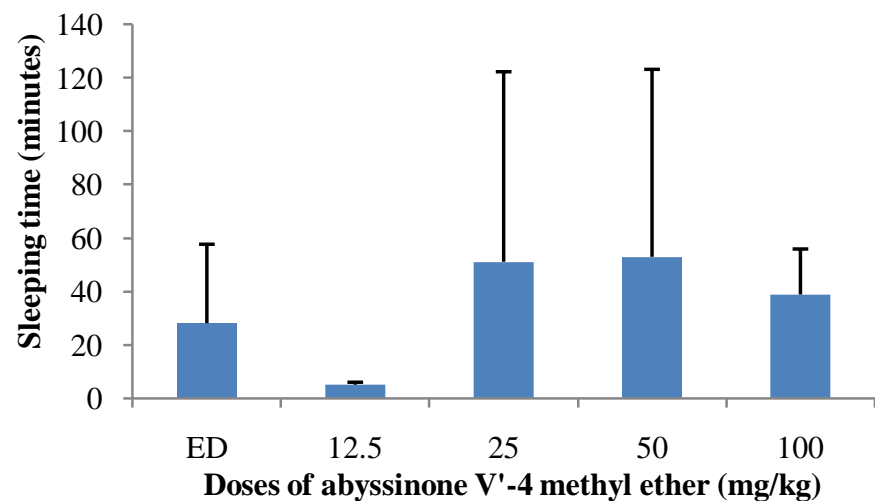

Fig. 2: Effect of Abyssinone on diazepam-induced on sleep time in mice.

\section{Effect of Abyssinone V-4' methyl ether PTZ-induced convulsions in mice}

Abyssinone at the dose of $100 \mathrm{mg} / \mathrm{kg}$ protected $100 \%$ of mice against PTZ-induced seizures ( $<$ < 0.001) (Fig.3).

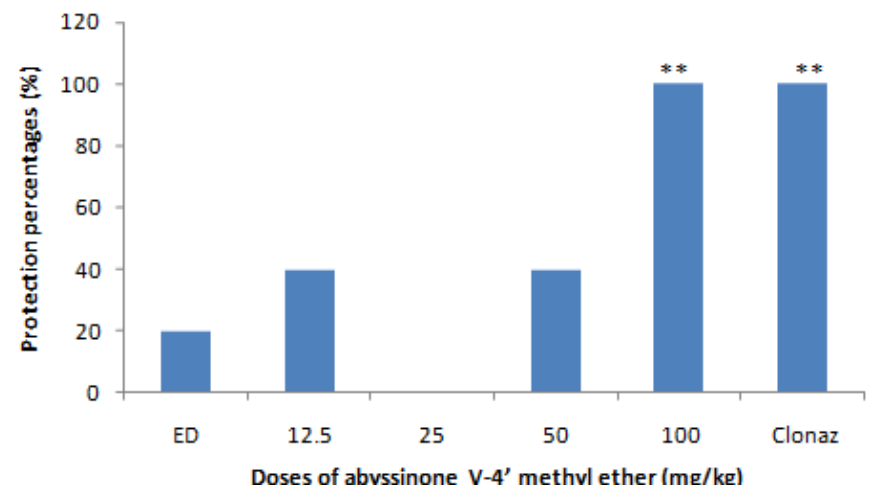

Figure 3: Effect of abyssinone V-4' methyl ether PTZ-induced on convulsions in mice.

\section{Effect of Abyssinone V-4' methyl etherPIC-induced convulsions in mice.}

The doses of 25 and $100 \mathrm{mg} / \mathrm{kg}$ provided all protection against PIC-induced seizures $(\mathrm{p}<0.001)$ and at a doses 12.5 and $50 \mathrm{mg} / \mathrm{kg}$ the extract protected $80 \%$ of mice $(\mathrm{p}<0.001)$ (fig. 4 )

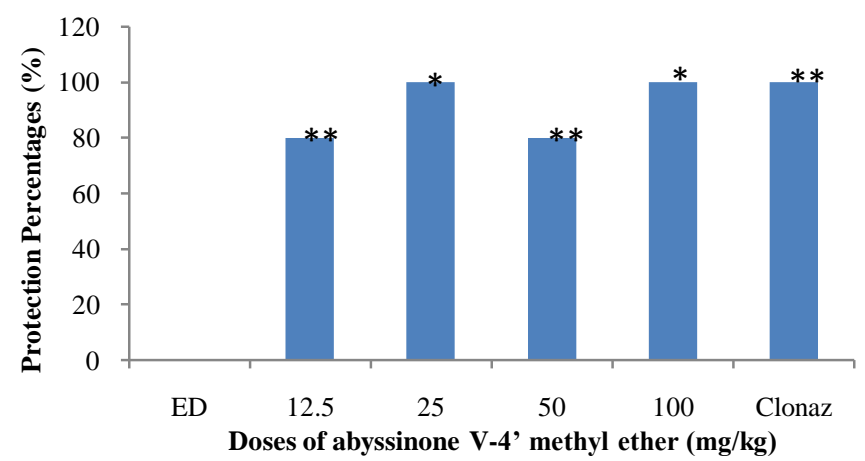

Fig. 4: Effect of abyssinone V-4' methyl ether PIC-induced on convulsions in mice.

\section{Effect of abyssinone V-4' methyl etherPILO-induced convulsions in mice.}

At doses of 25 and $50 \mathrm{mg} / \mathrm{kg}$, Abyssinone completely protected mice against PILO-induced convulsions $(\mathrm{p}<0.001)$ and $(\mathrm{p}<0.01)$ at doses of 12.5 and $100 \mathrm{mg} / \mathrm{kg}$, (Fig.5).

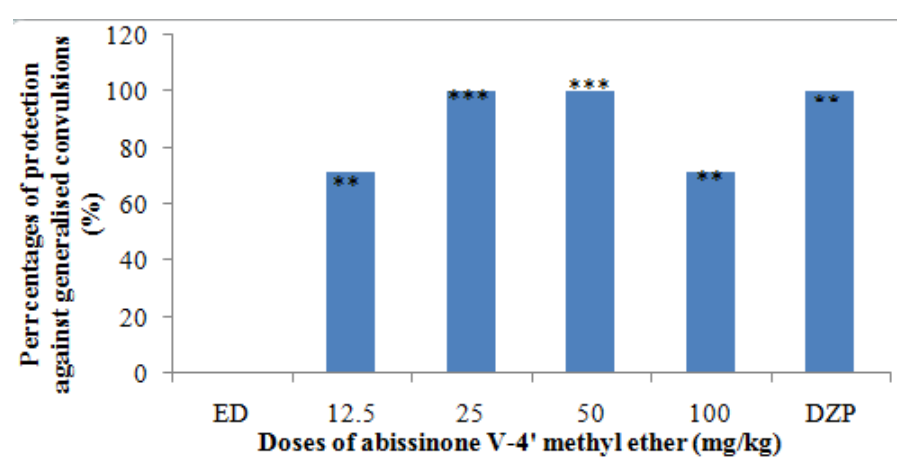

Fig. 5: Effect of abyssinone V-4' methyl ether PILO-induced on convulsions in mice.

Figure 6 presents the different stages reached by mice after administration of the pilocarpine. At doses of 25 and 50 
$\mathrm{mg} / \mathrm{kg}$, Abyssinone protected the mice $(\mathrm{p}<0.001)$ from dead one hour after the administration of PILO and protected the mice ( $\mathrm{p}<$ 0.001) 24hours after the administering the dose $50 \mathrm{mg} / \mathrm{kg}$ of Abyssinone, that which is more that the anticonvulsant reference drug.(fig.7).

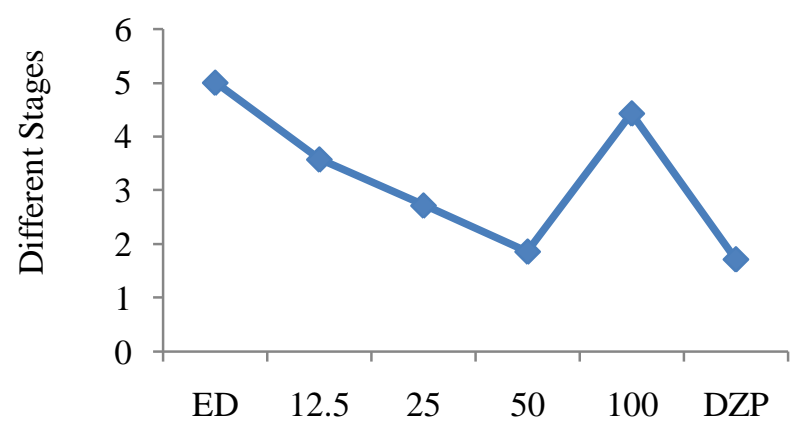

Doses of abyssinone V-4' methyl ether $(\mathrm{mg} / \mathrm{kg})$

Fig. 6: Effect of abyssinone V-4' methyl ether PILO- induced on the different stages in mice.

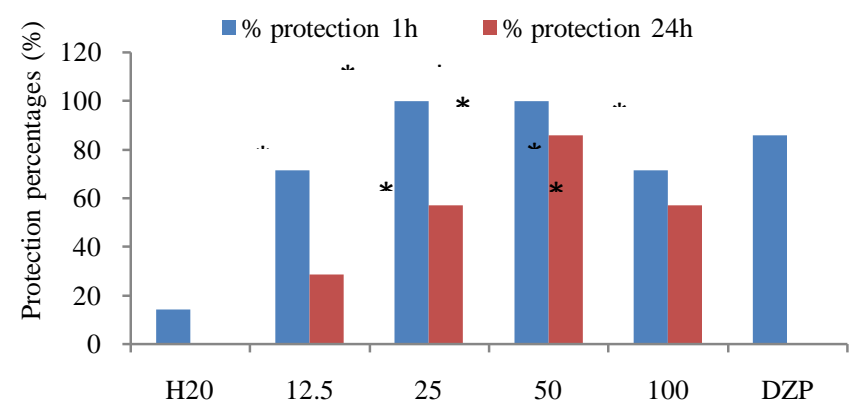

Doses of abyssinone V-4' methyl ether ( $\mathrm{mg} / \mathrm{kg})$

Fig. 7: Effect of abyssinone V-4' methyl ether PILO- induced on the death of mice.

\section{DISCUSSION}

Abyssinone did not potentialise the sleep time. The sedative properties are absent in this extracts (Ngo Bum et al., 2009a; 2009b; Rakotonirina et al., 2001). This result could be related to the absence of some components in the extracts activating the benzodiazepine, barbiturate and/or GABA receptors in the $\mathrm{GABA}_{\mathrm{A}}$ receptor complex (Bonin and Orser, 2008; Olkkola and Ahonen, 2008; Rang et al., 1999). While sodium thiopental that act on the barbiturate binding site directly gate the chloride ion channel of the $\mathrm{GABA}_{\mathrm{A}}$ receptor complex.

Abyssinone presents anticonvulsivant properties. This extract antagonizes the PTZ, PIC-and PILO-induced seizures, this suggests the interaction of these extract with the GABA-ergic neurotransmission (Salihand Mustafa, 2008; Perez-Saad and Buznego, 2008). GABA is the main inhibitory neurotransmitter substance in the brain and is widely implicated in epilepsy. Inhibition of GABA-ergic neurotransmission or activity has been shown to promote and facilitate seizures, while enhancement of GABA-ergic neurotransmission is known to inhibit or attenuate seizures (Li-Ping et al., 2008). Moreover, some studies showed that PTZ diminishes the GABA-ergic tone (Ahmadiani, 2003), probably by a competitive antagonist action on the BZD receptors (Rehavi et al., 1982). Drugs that enhance $\mathrm{GABA}_{\mathrm{A}}$-receptor neurotransmission, such as BZDs (Ahmadiani et al., 2003; White, 1997) can block seizures induced by PTZ.

PIC is known to be a non competitive GABA antagonist exerting his effect by blocking the chloride channel in the $\mathrm{GABA}_{\mathrm{A}}$ receptor complex. Isoniazide can enhance convulsions in patients with seizure disorders, and it is regarded as a GABA-synthesis inhibitor (Kale Shubhangi et al., 2010).

The antagonism of PILO -induced convulsions suggests the presence of anticonvulsant effect through in the limbic system, particularly in the hippocampus, entorhinal cortex and amygdala (Bartolomei et al., 2005). The subject of this review, the pilocarpine model, belongs to status Epileticus models. This model appears to be highly isomorphic with the human disease, so it has been used in many laboratories since its first description a quarter of a century ago (Turski et al., 1983a, b).

\section{CONCLUSION}

Abyssinone V-4' methyl ether did not show sedative properties but instead showed very good anticonvulsant activities against PTZ, PIC or PILO- induced seizures. However, Erythrina, medicinal plants could be used in the treatment of epilepsy.

\section{ACKNOWLEDGEMENTS}

The authors thank the Faculty of Science, University of Ngaoundere, Cameroon, for providing the necessary support for this study.

\section{REFERENCES}

Ahmadiani, A.; Mandgory,A. and Sayyah, M. Anticonvulsivant Effect of Flutamide on seizures induced by pentylenetetrazole, involvement of benzodiazepine receptors. Epilepsia, 2003; 44(5): 625-629.

Bernasconi R., Klein M., Martin P., Christen P., Hahner T., Portet C., Schumtz M. Gamma-Vinyl GABA: Comparison of neurochemical and anticonvulsivant effects in mice. Journal of neural transmission, 1988; 7: 213-233.

Bartolomei F, Chauvel P, Wendling F. Spatio-temporal dynamics of neuronal networks in partial epilepsy. Rev Neurol (Paris), 2005; 161: 767-80.

Bonin, R. P. and Orser, B.A. $\mathrm{GABA}_{\mathrm{A}}$ receptor subtypes underlying general anesthesia. Pharmacology Biochemistry and behavior, 2008; 90(1): 105-112.

Ethel A., Wilhelm., Cristiano R., Jesse., Silvane S., Cristiani F., Bortolatto., Cristina W., Nogueira. Anticonvulsant effect of (E)-2benzylidene-4-phenyl-1,3-diselenole in a pilocarpine model in mice. Life Sciences, 2010; 87: 19-22.

Diop AG.,Ndiaye M, Thiam A., et al. Filière des soins antiépileptiques en Afrique. Epilepsies, 1996; 10: 115-121.

Geoffrey c andKirby M. Medicinal plants and the control of protozoa disease with particular reference to malaria. Transaction of the Royal Society of Tropical Medicine and Hygiène, 1996.

Henrik Klitgaard, Alain Matagne, Renee Grimee, Jocelyne Vanneste-Goemaere, Doru-Georg Margineanuel. Ectrophysiological, neurochemical and regional effects of levetiracetam in the rat pilocarpine model of temporal lobe epilepsy. The journal of the British Epilepsy Association, 2003; 12(2): 92-100. 
Kale Shubhangi, S.; SheteRajkumar, V., Korekakasahed, J.; PatilBhaskar, M., BhutadaRupesh, N., pattankudeVinod. Anticonvulsant activity of Glycyrrhizic acid in mice. International Journal of Pharmaceutical researches and development, 2010;12(2).

Kamat VS, Chuo FY, Kubo I, Nakanishi K. Anti-microbial agents from an East-African medicinal plant, Erythrina abyssinica. Heterocycles, 1981; 15: 1163-1170.

Kebenei JS, Ndalut PK, Sabah AO. Synergism of artemisinin with abyssinone-V from Erythrina abyssinica (Lam. ex) against Plasmodium falciparum parasites: A potential anti-malarial combination therapy. Journal of Medicinal Plants Research, 2011; 5: 1355-1360.

Kone WM, Solange KN, Dosso M. Assessing sub-saharan Erythrina for efficacy: traditional uses, biological activities and phytochemistry. Pak j boil Sci, 2011; 14(10): 560-71.

Lehmann J., Hutchison A., MCPherson S.E., Mondadori C., Schmutz M., Sinton C.M., Tsai C., Murphy D.E., Steel D.J., Williams M., Cheney D.L., Wood P.L. CGS 19755, a selective and competitive Nmethyl-D-aspartate excitatory amino acid receptor antagonist, Journal of Pharmacology and Experimental Therapeutics, 1988; 246: 65-75.

Li-Ping, G., Xian-Yu, S.; Guan-Rong, T.; Kyu-Yun, C. and Zhe-shan, Q.The Synthesis and Anticonvulsant Activity of 1- Substituted 7- Methoxy -1,2,4- Triazolo [4, 3-a] Quinoline. Turkish Journal of Chemistry, 2008; 32(2),: 181-189.

Maiti A, Cuendet M, Croy VL, Endringer DC, Pezzuto JM, CushmanM. Synthesis and biological evaluation of (+/-)-abyssinone II and its analogues as aromatase inhibitors for chemoprevention of breast cancer. J Med Chem, 2007; 50(12): 2799-806.

Mvondo MA, Njamen D, Fomum S, Wandji J. Effects of alpinumisoflavone and abyssinone V-4'-methyl ether derived from Erythrina lysistemon (Fabaceae) on the genital tract of ovariectomized female Wistar rat. Phytotherapy Res, 2012; 26(7): 1029-36.

Mustafa AMS, Ali AM. Substance in broad beans (Viciafaba) is protective against experimentally induced mice convulsions in mice. Epilepsy Behavior, 2008; 12: 25-9.

Na MK, Jang JP, Njamen D, Mbafor JT, Fomum ZT, Kim BY, Oh WK, Ahn JS. Protein Tyrosine Phosphate -1B Inhibitory Activity of Isoprenylated Flavonoids isolated from Erythrina mildbraedii. J Nat Prod, 2006; 69(11): 1572-1576.

Ngounou EB., Quet F, Dubreuil CM, Marin B, Houinato D, Nubukpo P, Dalmav F, Druet-Cabanac M and Preux PM. Epidémologie de l'épilepsie en Afrique subsaharienne: une revue de la littérature. Cahiers d'études et de recherche francophones/Santé, 2007; 16(4) : 225-228.

Njamen D, Talla E, Mbafor JT, Fomum ZT, Kamanyi A, Mbanya JC, Cerda-Nicolas M, Giner MR, Recio CM, Rios JL. Antiinflammatory activity of erycristagallin, a pterocarpene from Erythrina midbraedii. Eur J Pharmacol, 2003 ; 468: 67-74.

Njamnshi A. K., Bissek A-C., Tabah E.N., Angwarfor S.A., Kuate C.T Déma F., Fonsaf T.Y., Acho A., Kepeden M-N.Z-K., Azinwi Y.H., Kuwoh P.B. Angwafor III F.F., Muna W.F.T. Community survey of Knowledge, perceptions, ad practice with respect to epilepsy among traditional hearlers in the Batibo Health District, Cameroon. Epilepsy and behavior, 2010; 17:95-102.

Ngo Bum E., Schmutz M., Meyer C., Rakotonirina A., Bopelet M., Portet C., Jeker A., Rakotonirina S.V., Olpe H.R., Herrling P. Anticonvulsant properties of methanol extract of Cyperus articulatus (cyperaceae). Journal of Ethno pharmacology, 2001; 87: 27-34.

Ngo Bum E., Sidiki N., Taiwe G., Seke P. F., Maidawa F., Rakotonirina S. V., Rakotonnirina A. Sedative and anticonvulsant properties of the decoction of Balanites aegyptica. Journal of Animal and Veterinary Advances, 2005; 4:34-38.

Ngo Bum, E; Taiwe, G.S.; Nkaissa, L.A.; Moto, F.C.O.; Seke, E.P.F.; Hiana, I.R.; Bailabar, T.; Rouyatou; Seyni, P.; Rakotonirina,A and Rakotonirina, S.V. Validation of anticonvulsivant and sedative activity of six medicinal plants. Epilepsy and behavior, 2009a; 14(3): 454-458.

Ngo Bum, E; Taiwe, G.S.; Moto, F.C.O.; Ngoupaye G.T.; Nkantchoua G. C.N.; Pelanken M.M.; Rakotonirina, S.V and Rakotonirina, A. Anticonvulsivant, anxiolytic and sedative properties of the roots of Nauclea latifolia Smith in mice. Epilepsy and behavior, 2009b; 15(4): 434-440.
Ngo Bum, G.N. Nkantchoua, N. Njikam, G.S. Taiwe, G.T. Ngoupaye, M.M.Pelanken, Nanga, F. Maidawa, A. Rakotonirina and S.V. Rakotonirina. Anticonvulsivant and Sedative Activity of Leaves of Senna spectabilis in Mice, International Journal of Pharmacology, 2010; 6 (2): 123-128.

Ngo Bum, M.M.Pelanken, N. Njikacvm, E Talla, G.S. Taiwe, G.C.N. Nkantchoua, G.T. Ngoupaye. The Decoction of Leaves of Phyllanthus discoideus Possesses anticonvulsant and sedative properties in Mice. International Journal of Pharmacology, 2009; 5(2): 168-172.

Olkkola, K.T. and Ahonen, J. 2008. Midazolam and other benzodiazepines. Handbook of experimental Pharmacology. Pp. 335-360.

Perez-Saad, H. and M.T. Buznego. Behavioral and antiepieleptic effects of acute administration of the extract of the plant Cestrium nocturmum Lin (Lady of the night). Epilepsy and behavior, 2008; $12(3): 366-372$

Rakotonirina, S.V; Ngo Bum E.;Rakotonirina, A. and Bopelet, M. Sedative properties of the extract of the rhizome of Cyperus articulatus. Fitoterapia, 2001; 72(1): 22-29.

Rang, H.P., Dale, M.M., Ritter, 1999. J.M. Pharmacology. Churchill Livingstone. New York, USA.

Rao GV, Swamy BN, Chandregowda V, Reddy GC. Synthesis of (+/-) Abyssinone 1 and related compounds: Their antioxidant and cytotoxic activities. Eur J Med Chem, 2009; 44(5): 2239-45.

Rehavi, M., Skolnick, P., and Paul, S.M. Effects of tetrazole derivatives on $[3 \mathrm{H}]$-diazepam binding in vitro: correlation with convulsant potency. European Journal of Pharmacology, 1982; 78(3): 353-356.

Salih, M.A. and Mustafa, M.M. A substance in broad beans (Victafaba) is protective against experimentally induced convulsions in mice. Epilepsy and behavior, 2008; 12(1): 25-29.

Turski WA, Cavalhero EA, Schwarz M, Czucwar SJ, Kleinrok $\mathrm{Z}$ and Turski L. Limbic seizures produced by pilocarpine in rats: Behavioural, electroencephagraphic and neuropathological study. Behav Brain Res, 1983a; 9: 315-335.

Turski WA, Czucwar SJ, Cavalhero EA, Schwarz M, Turski L and Kleinrok Z. Acute and long-term effects of systemic pilocarpine en rats: spontaneous recurrent seizures as a possible model of temporal lobe epilepsy. Naunyn-Schmiedeberg's Arch Pharmacol, 1983b; 324: 25R.

Wandji J, Fomum ZT, Tillequin F, Seguin E, Koch M. Erythrina studies: Part 24. Two isoflavones from Erythrina senegalensis. Phytochemistry, 1994; 35: 245-248.

Wamil A.W., Schmutz M., Portet C., Feldman K.F., Michael J. Mcl. Effect of oxcarbamazepine and 10- hydrocarbamazepine on action potential firing and genaralised seizure. E. J. of Pharmacolgy, 1994; 271: 301-308.

White, H.S. 1997. New mechanisms of antiepileptic drugs, In: Porter R., Chadwick D., (Ed):1-30, Butterworth Heinemann, Boston, USA.

Yenesew A, Midiwo JC, Heydenreich M, Peter MG. Two prenylated flavonones from stem bark of Erythrina burttii. Phytochemistry, 1998 ;48: 1439-1443.

\section{How to cite this article:}

TALLA Emmanuel, NGATCHA Sidoine, NJAPDOUNKE Jacqueline, NKANTCHOUA Gisèle, YAYA Gbaweng Abel Joël, NGO BUM Elisabeth, MBAFOR TANYI Joseph, NJINTANG YANOU Nicolas. Anticonvulsivant and sedative like-effect of Abyssinone V-4' methyl ether Isolated from Erythrina droogmansiana (Leguminosae). J App Pharm Sci, 2015; 5 (10): 001-005. 